\title{
Computer analysis of benthic foraminiferal associations in a tidal New Zealand inlet
}

\author{
BRUCE W. HAYWARD ${ }^{1} \&$ CHRISTOPHER M. TRIGGS ${ }^{2}$ \\ ${ }^{1}$ Auckland Institute and Museum, Private Bag 92018, Auckland, New Zealand. \\ ${ }^{2}$ Mathematics and Statistics Department, University of Auckland, Private Bag 92019, Auckland, New Zealand.
}

\begin{abstract}
Census data on benthic foraminiferal tests in 45 surface sediment samples from Pauatahanui Inlet, Wellington, New Zealand, are analysed by Correspondence Analysis and Non-Hierarchical classification techniques. The faunas are grouped into 7 associations: (A) Trochamminita irregularis/Miliammina fusca - at high tide level in a small tidal creek at the limits of salt water influence; (B) Trochammina inflata/Jadammina macrescens - in an extreme high tidal pool, close to the mouth of a small stream; (C) Miliammina fusca/Haplophragmoides wilberti/Trochammina inflata - intertidal and shallow subtidal (to $0.6 \mathrm{~m}$ depth), muddy sand over a large area in the upper reaches of the inlet, where most freshwater runoff enters; (D) Elphidium excavatum/Miliammina fusca - intertidal muddy sand associated with shelly beaches on the fringe of association C; (E) Ammonia beccarii/Haynesina depressula - in a wide variety of intertidal and shallow subtidal (to $3 \mathrm{~m}$ depth) sediments that form a belt between the more brackish associations (A-D) and the more normal salinity associations (F-G); (F) Bolivina cf. translucens/Textularia earlandi/Bolivina subexcavata - in mud to muddy, very fine sand in a shallow basin (1-2.5 $\mathrm{m}$ deep) in the middle of the inlet and in a small, sheltered backwater; (G) Elphidium charlottensis/Patellinella inconspicua/ Quinqueloculina seminula - in sandy mud and muddy fine sand, intertidal to $10 \mathrm{~m}$ depth, in the mouth, entrance channel and adjacent outer and middle parts of the inlet, where a flush of normal salinity water enters during each tidal cycle.

Using Canonical Correspondence Analysis, the factors most influential in determining the faunal distribution are, in decreasing importance: freshwater influence (salinity), exposure to the air during tidal cycles, proximity to the open sea, tidal current strength and percentage of mud in the substrate. J. Micropalaeontol. 13(2): 103-117, December 1994.
\end{abstract}

\section{INTRODUCTION}

New Zealand's fossil and modern, foraminiferal faunas from normal marine environments, are well documented, but brackish foraminifera have received little attention.

This paper describes the benthic foraminiferal associations in 45 surface sediment samples from Pauatahanui Inlet (Fig. 1). The samples come from a broad range of shallow environments (high tide to $10 \mathrm{~m}$ depth) extending from the extreme limits of brackish influence to normal salinity. Pauatahanui Inlet is the eastern arm of Porirua Harbour (latitude $41^{\circ} 05^{\prime} \mathrm{S}$, longitude $175^{\circ} 50^{\prime} \mathrm{E}$ ), on the northwest coast of Wellington region, New Zealand (Fig. 1). Most of the 500 ha inlet is shallower than $2.5 \mathrm{~m}$ depth (Fig. 1) with a wide $(100-800 \mathrm{~m})$, intertidal fringe, especially around its upper reaches where a large area of salt marsh is present. Sandy, intertidal shoals cover a large portion of the northwest, lower reaches of the inlet. The greatest depths $(3-10 \mathrm{~m})$ are in the narrow, current-swept, entrance channel, which snakes its way for $2 \mathrm{~km}$ in towards the middle of the inlet (Fig. 1). The mouth of Pauatahanui Inlet is filled by a Holocene sand spit, leaving only the $120 \mathrm{~m}$-wide, entrance channel to provide communication with the open sea. Brackish conditions are concentrated around the upper reaches of the inlet, where $95 \%$ or more of freshwater runoff enters via five streams, with Horokiwi and Pauatahanui Streams, contributing $75 \%$ of this.
Sediments (Fig. 2a)

Pauatahanui Inlet's central, shallow basin (1-2.5 m) has a muddy floor with sandy mud around its fringes. Muddy to slightly muddy, very fine sand covers much of the northern and southern sides of the middle and lower reaches, becoming fine sand around the upper reaches $(0-1 \mathrm{~m}$ depth). The intertidal and shallow subtidal shoals in the northwest are composed of similar, slightly muddy, fine sand. Pebbly and shelly sand forms the beaches around many parts of the inlet and shelly fine sand lines the entrance channel and seafloor outside its mouth.

\section{METHODS}

Samples 1-34 were collected by New Zealand Oceanographic Institute scuba divers, who scooped the upper $5-10 \mathrm{~cm}$ of bottom sediment into a jar using a small hand shovel (McDougall, 1976). Intertidal samples 35-45 were collected in the same way by the author during low tide.

Foraminiferal tests (dead plus live) were concentrated by flotation with carbon tetrachloride and divided using a microsplitter to give approximately 100 benthic forms for total assemblage analysis. Any planktic foraminifera encountered were also picked.

Previous studies indicate that 100 specimens provide a sufficiently accurate assessment of faunal composition for use in identifying and mapping associations as the computer 


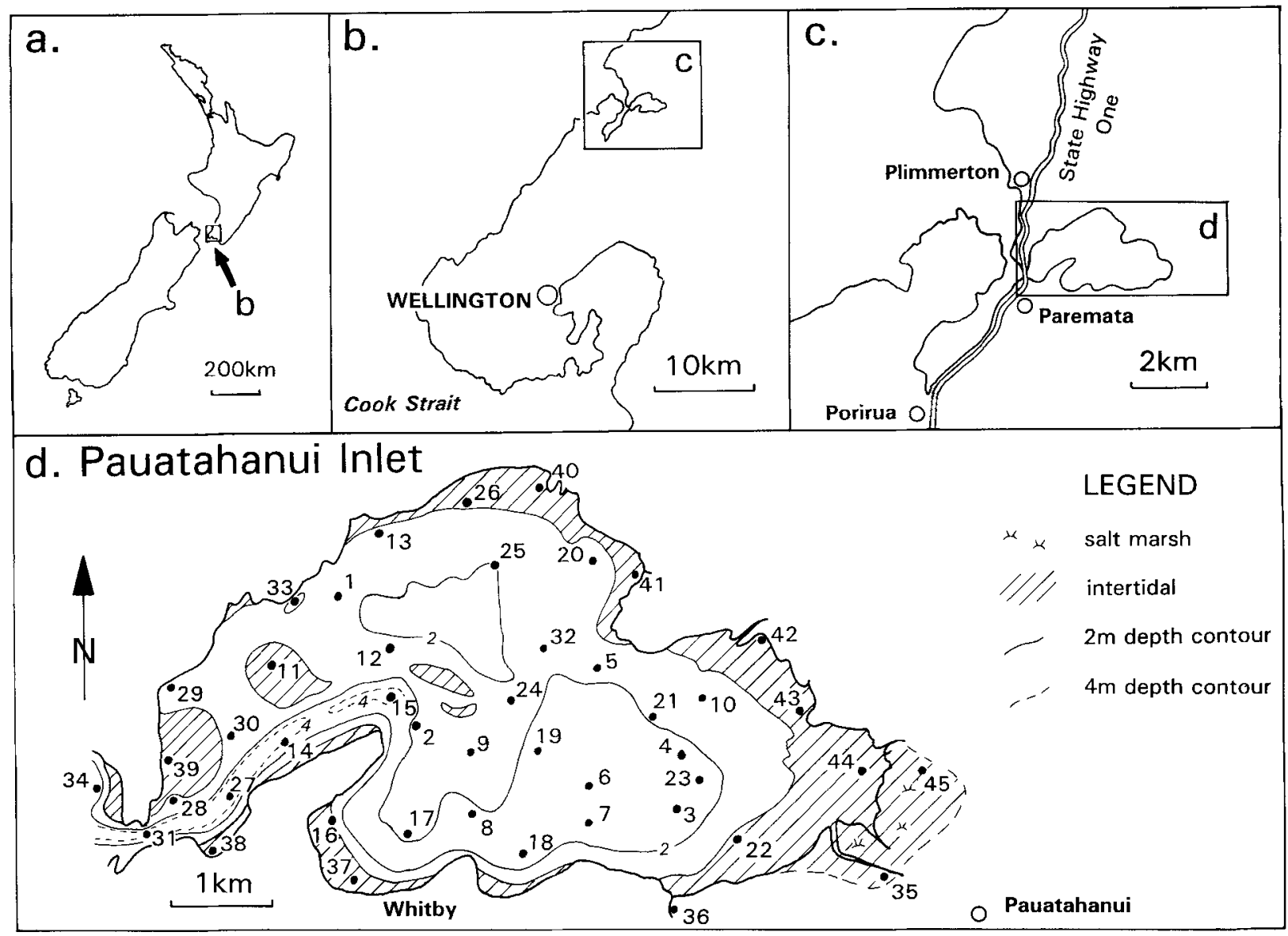

Fig. 1. Depth contours (from Irwin, 1978) and sample locations in Pauatahanui Inlet (d), an arm of Porirua Harbour (c) on the northwest coast of Wellington region (b), New Zealand (a).

programmes employed are primarily influenced by the dominants in each fauna. The extra work in picking 200 or 300 benthic tests cannot be justified in a study of this sort.

All faunas are held in the Micropaleontology Section of the New Zealand Geological Survey (samples F201992202037). Figured specimens (Plates 1,2) have catalogue numbers prefixed by FP. A full list of foraminifera identified in Pauatahanui Inlet is given in Appendix 1.

\section{STATISTICAL METHODS}

The data consist of counts of 99 species in 45 samples. Because the number of individuals picked was standardized at around 100 benthic forms, the data are more analogous to species proportions than species densities. The data matrix was standardized by converting counts to proportions of sample totals. The technique of detrended correspondence analysis, using the programme CANOCO (Ter Braak, 1985), was used to summarize the data. A representation of the 45 samples in 4-dimensional space was produced. The co-ordinates of a sample in each of the 4 dimensions are weighted averages of all the species proportions. This representation was used as an input to a technique using an exchange algorithm non-hierarchical clustering, with the distance between the points defined to be Euclidian distance (Banfield \& Bassill, 1977), using the program GENSTAT (Payne et al., 1987).

\section{Association score (Table 1)}

To determine which species characterize each of the 7 faunal associations, the 99 taxa were ranked for each association using a value (association score) calculated to reflect their importance, based on a combination of 5 criteria (modified after McCloskey, 1970 and Grange, 1979):

1. Dominance (Dom). The 10 most abundant taxa of each station in an association were scored with most abundant species given a score of 10 , the second most abundant a score of 9 , and so on. The dominance of a taxon within an association is given by the mean score across all stations.

2. Fidelity (Fid), or degree to which a taxon is restricted to an association expressed as the proportion of stations within the association in which the taxon occurs less the proportion of stations outside the association in which it occurs.

3. Abundance (Abund), given as the mean abundance of the taxon within the association.

4. Relative abundance (Rel), expressed as the mean 


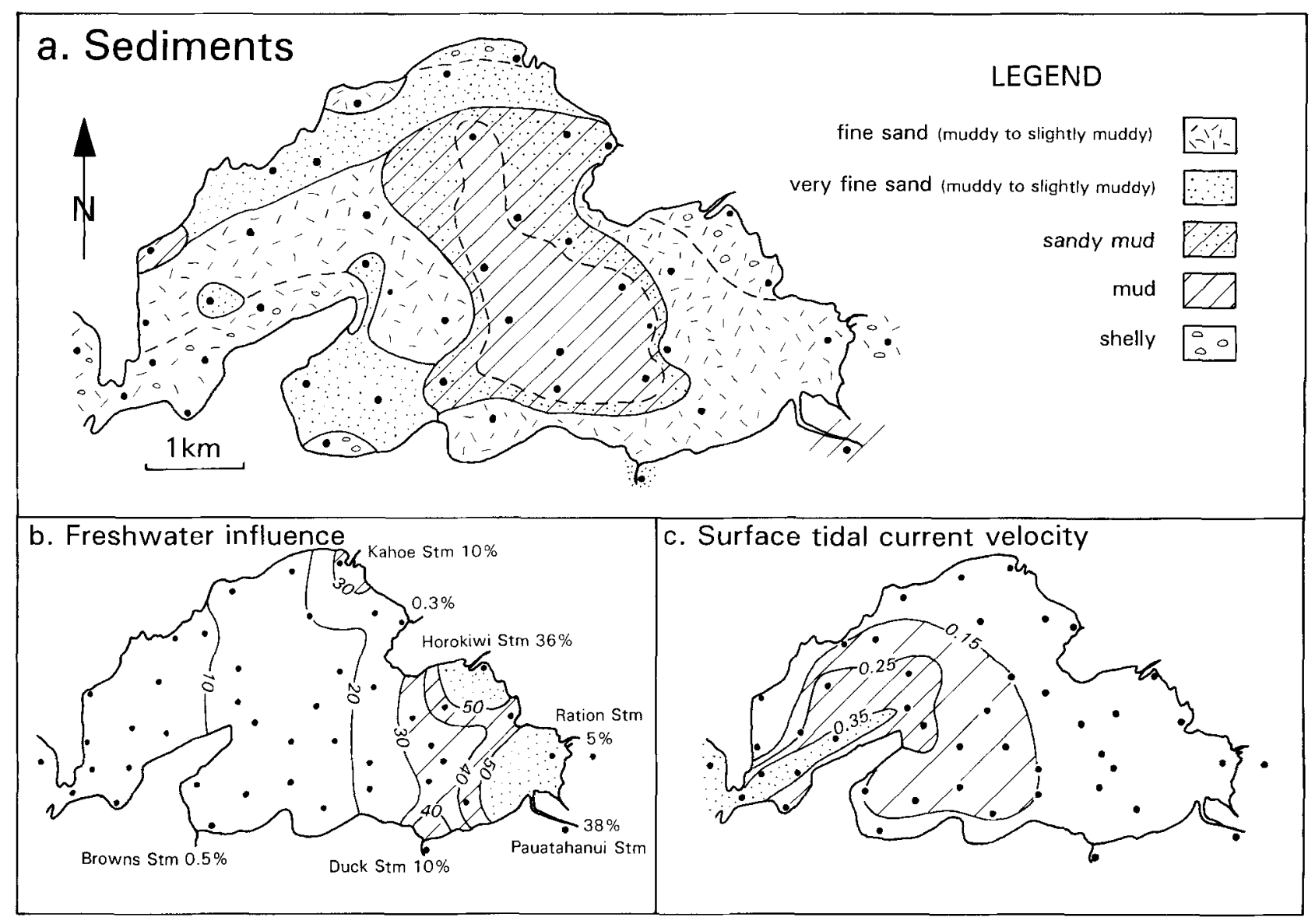

Fig. 2. (a) Simplified sediment distribution map of Pauatahanui Inlet (based on grain size analysis of present samples with additional data from McDougall, 1978). (b) Contoured freshwater influence map of Pauatahanui Inlet. Produced by calculating a value for each station, being the sum of the reciprocals of the distances between the station and the mouths of the seven main streams that enter the inlet, each having been first multiplied by their percentage contribution of freshwater runoff to the inlet (data from Healy, 1980). (c) Contoured surface tidal current velocity map of Pauatahanui Inlet. Produced using the model data of Healy (1980: 163).

abundance of the taxon within the association less its mean abundance throughout all the stations.

5. Persistence (Pers), given as the proportion of the stations within the association in which the taxon occurs.

The various criteria were weighted and combined to give an empirical Association score for each species in each association, with a maximum value of 100. Association scores were calculated using the formula:

$$
\text { 4(0.3 Dom }+2 \text { Fid + 0 } 11 \text { Abund + 0.08 Rel + Pers }) .
$$

Weightings have been assigned to each criterion to make their values more nearly equal but to give greater weight to some criteria in the following decreasing order: Abundance, Relative Abundance, Dominance, Fidelity, Persistence.

\section{Species diversity}

Three measures of species diversity have been calculated for each fauna, and also the mean values for each of the associations:

1. Number of species, $S$, in the fauna.
2. Shannon-Wiener Information Function, $\boldsymbol{H}_{(S)}=\sum P_{i} \log _{\mathrm{c}} P_{i}$ where $P_{i}$ is the proportion of the $i$ th species (MacArthur \& MacArthur, 1961; Gibson \& Buzas, 1973). Unlike $S$, the Information Function places little weight on rarer and very abundant species. The value of $H$ depends on a combination of the evenness of species counts together to a lesser extent with the number of species present.

3. Evenness, $\boldsymbol{E}=\mathrm{e}^{\prime \prime} / S$, is a measure solely of evenness of species counts within a fauna, irrespective of the number of species present (Buzas \& Gibson, 1969; Hill, 1973).

\section{Environmental factors}

To relate the compositjons of the samples to the environmental factors observed, the technique of canonical correspondence analysis (Ter Braak, 1987), using the program CANOCO, was used.

The following environmental 'factors' were scored for each station and utilized in the CANOCO analysis to determine which were most likely to be producing the 
foraminiferal faunal pattern:

1. Gravel-percentage of sediment composed of gravel fraction.

2. Sand-percentage of sediment composed of sand fraction. 3. Mud - percentage of sediment composed of mud fraction. 4. Depth - water depth below mean spring high tide.

5. Exposure - proportion of time exposed above water level during tidal cycles.

6. Open sea-distance of the station from the inlet mouth expressed as a proportion of the distance between the head of the inlet and the mouth.

7. Current-surface tidal current velocity obtained by measuring the distance travelled by floating confetti during time lapse photography of the filling of a model of the inlet (Healy, 1980: 163), expressed as a proportion of the greatest current strength in the inlet mouth (Fig. 2c).

8. Freshwater influence - calculated as the sum of $x / d$ for each of the seven main streams feeding into Pauatahanui Inlet, where $x=$ the percentage of the total stream inflow contributed by stream $i$ (Fig. 2b, from Healy, 1980) and $d=$ distance of the station from the mouth of stream $i$. Index values have been standardized between 0 and 100 (Fig. 2b). This method of assessing the influence of salinity is believed to be more appropriate than a set of one-off salinity measurements, the values of which will depend on the state of the tide and the level of freshwater input from the streams.

9. Wave - wind-generated wave index, $W=(2 N W+S)(1-$ $E$ ) where $N W=$ the distance between the station and the inlet coastline in a north-northwest direction (the dominant direction of winds over 10 knots, Healy, 1980: 150) as a proportion of the greatest possible distance; $S=$ the distance between the station and the coastline in a southerly direction (the subdominant direction of winds over 10 knots, Healy, 1980: 150) as a proportion of the greatest possible distance; $E=$ exposure, above.

No values for nutrients or oxygen were available, but both are generally strongly correlated positively and negatively, respectively, with mud content.
FORAMINIFERAL ASSOCIATIONS (Figs 3, 4, Table 1)

A plot of the sample scores on the first 2 dimensions of Correspondence Analysis is given in Fig. 3. After examination of the output from non-hierarchical classification, the samples were split into two groups - one brackish, the other closer to normal salinity. The data set was split, and separate non-hierarchical classification clustering was performed on the 9 brackish samples and the 36 near-normal salinity samples. The following 4 brackish associations (A-D) and 3 near normal salinity associations (E-G) were recognized.

\section{Association A - Trochamminita irregularis/Miliammina fusca}

Depth : high tide. Sediment: muddy, very fine sand.

This association is recorded from only one station, located at the head of a small tidal creek, and undoubtedly is the lowest salinity sample.

The agglutinated foraminifera Trochamminita irregularis and Miliammina fusca are the dominant and characterising species. Trochamminita comprises $60 \%$ of this fauna and is extremely rare in all other associations (fidelity $=1$ ). The only calcareous taxon in this association is one specimen of Elphidium advenum.

This association is known from only a few, similar, low salinity environments elsewhere in the world-in South Australia, Trinidad and Brazil (Murray, 1991).

\section{Association B - Trochammina inflata/Jadammina macrescens}

Depth : high tide. Sediment : slightly shelly, sandy mud.

This association is only recorded from one station, a high intertidal pool having periodic low salinity caused by freshwater inflow from an adjacent small stream. Nearnormal salinity would be reinstated at every high tide. The association is dominated by agglutinated Trochammina

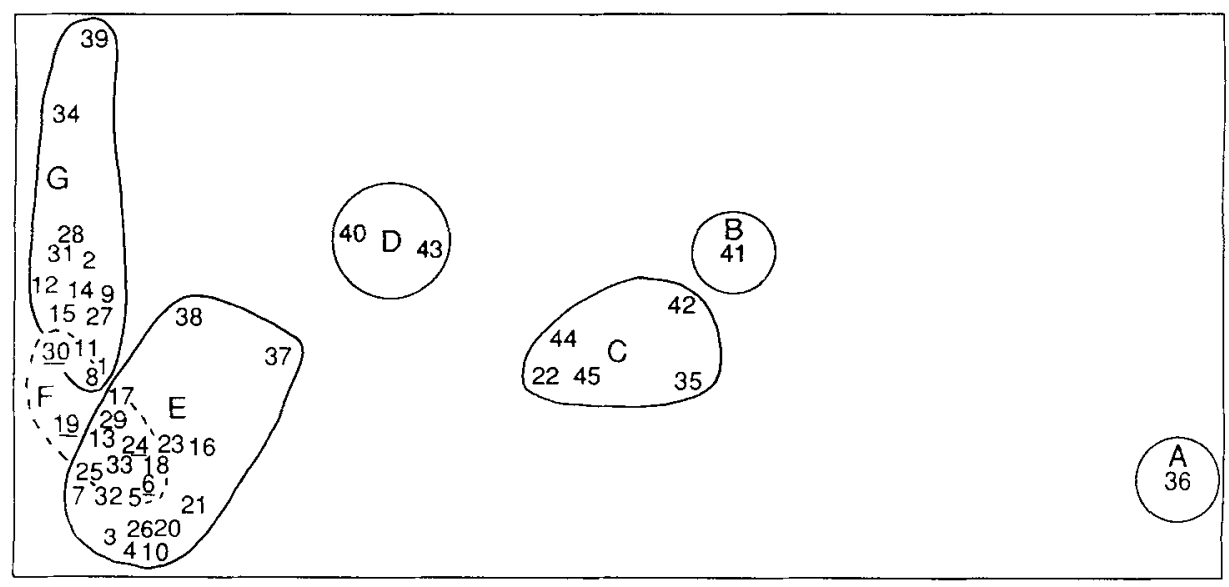

Fig. 3. Two-dimensional configuration of samples produced by Detrended Correspondence Analysis with the seven associations produced by non-hierarchical classification superimposed. Samples in association $\mathrm{F}$ are underlined. 


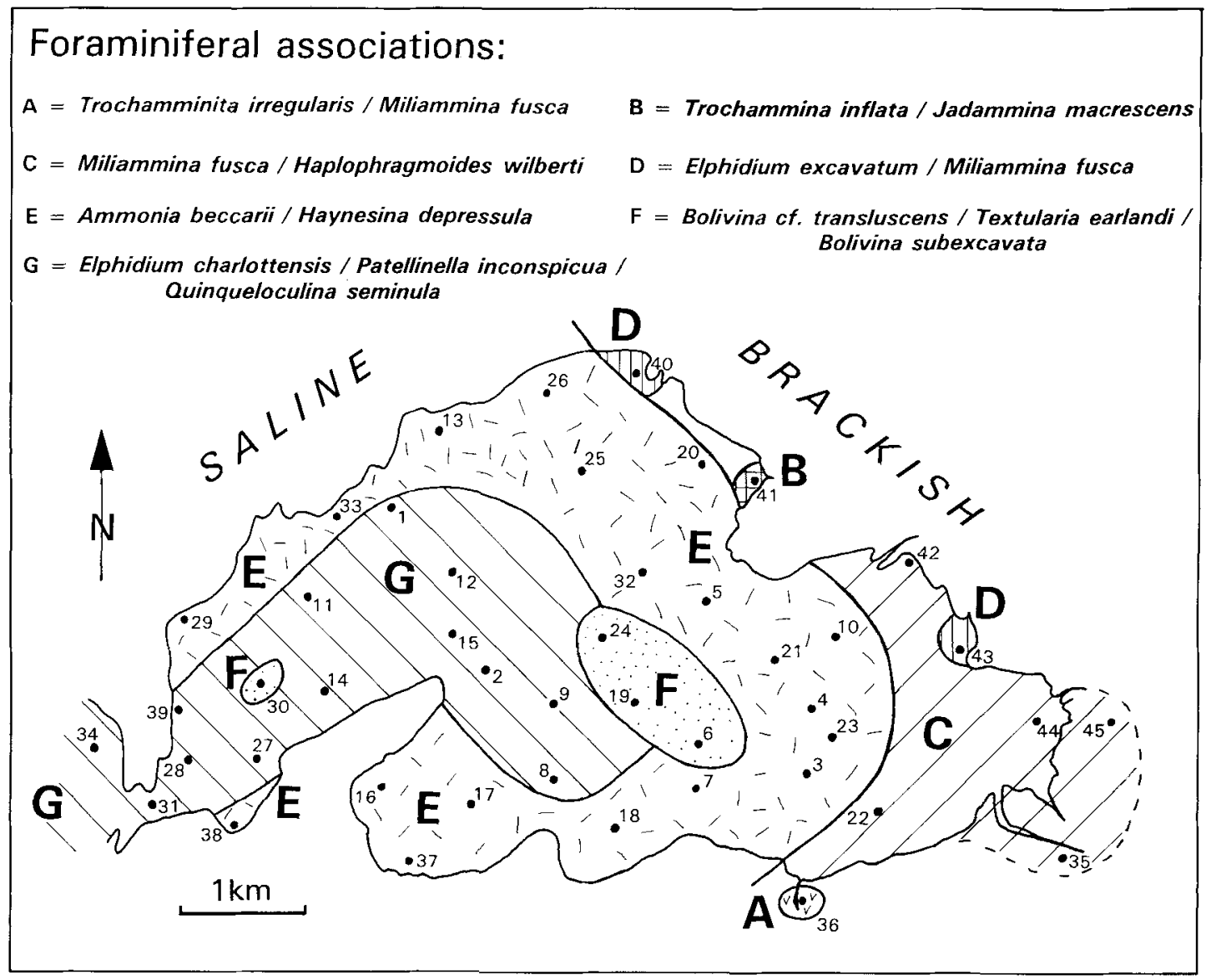

Fig. 4. Distribution of the seven benthic foraminiferal associations in Pauatahanui Inlet, showing brackish associations (A-D) around the head and more saline associations (E-G) around the mouth.

inflata $(89 \%)$ and also characterized by fragile, agglutinated Jadammina macrescens $(6 \%)$, which occurs only rarely in other brackish associations.

This association is the common high marsh fauna occuring above mean high water along the mid-latitude coasts of North and South America (Murray, 1991).

\section{Association C - Miliammina fusca/Haplophragmoides wilberti/Trochammina inflata}

Depth : $0.6 \mathrm{~m}$ to high tide. Sediment : mud to shelly, slightly muddy, fine sand.

This association occurs around the upper reaches of Pauatahanui Inlet in the area where $90 \%$ of the inlet's freshwater runoff enters. Thus salinity here, even at high tide would be lower than nearer the mouth. The association extends from just below low tide level, across the extensive intertidal sandy mudflats into the surrounding salt marsh at high tide level.

Miliammina fusca is dominant in each sample (mean abundance $56 \%$ ) with Haplophragmoides wilberti and Trochammina inflata the secondary dominants. All three have high relative abundance and fidelity values here. The rare agglutinated Ammotium fragile is recorded almost exclusively from salt marsh sample 35 where it comprises $15 \%$ of the fauna.
Upper estuarine environments around the world are mostly dominated by Miliammina fusca. Haplophragmoides (often $H$. wilberti) is abundant in association with Miliammina in some Australian, European, Caribbean and South American estuaries (Murray, 1991).

Association D - Elphidium excavatum/Miliammina fusca Depth : intertidal. Sediment : slightly shelly, muddy to slightly muddy, very fine to medium sand.

This association occurs in two mid-tidal stations near the foot of the somewhat shelly, sandy beach that forms the fringe of the inlet along much of its northeastern side. Salinity would be similar to or fractionally higher than association $\mathrm{C}$.

Elphidium excavatum is the dominant species in both samples (mean abundance 63\%) with Miliammina fusca the secondary dominant. Trochammina inflata and Ammonia beccarii are also common.

This association is common worldwide in middle estuary environments (Murray, 1991).

Association E - Ammonia beccarii/Haynesina depressula Depth: $3 \mathrm{~m}$ to high tide. Sediment : mud to slightly muddy, fine sand and slightly muddy, sandy shell gravel.

This association occurs in a belt around the margins of the 


\begin{tabular}{|c|c|c|c|c|c|c|}
\hline & Abund & Fid & Pers & Dom & Rel & $\begin{array}{l}\text { Assoc } \\
\text { Score }\end{array}$ \\
\hline \multicolumn{7}{|c|}{ Association A - Trochamminita irregularis/Miliammina fusca (stn. 36) } \\
\hline Trochamminita irregularis & 59.0 & 1.0 & 1.0 & 10.0 & 57.7 & 68.2 \\
\hline Miliammina fusca & 37.1 & 0.6 & 1.0 & 9.0 & 28.6 & 45.2 \\
\hline Jadammina macrescens & 1.9 & 0.9 & 1.0 & 8.0 & 1.5 & 21.8 \\
\hline \multicolumn{7}{|c|}{ Association B - Trochammina inflata/Jadammina macrescens (stn. 41) } \\
\hline Trochammina inflata & 88.6 & 0.7 & 1.0 & 10.0 & 84.5 & 87.9 \\
\hline Jadammina macrescens & 5.7 & 0.9 & 1.0 & 9.0 & 5.3 & 25.9 \\
\hline \multicolumn{7}{|c|}{$\begin{array}{l}\text { Association C-Miliammina fusca/Haplophragmoides wilberti/Trochammina inflata (stns } 22,35,42 \\
44,45 \text { ) }\end{array}$} \\
\hline Miliammina fusca & 55.6 & 0.7 & 1.0 & 10.0 & 47.1 & 61.0 \\
\hline Haplophragmoides wilberti & 9.0 & 0.9 & 1.0 & 6.6 & 7.8 & 25.2 \\
\hline Trochammina inflata & 12.6 & 0.6 & 0.8 & 6.2 & 8.6 & 23.6 \\
\hline Jadammina macrescens & 1.5 & 0.7 & 0.8 & 3.6 & 1.1 & 14.4 \\
\hline Elphidium excavatum & 3.1 & 0.1 & 0.8 & 3.8 & -3.0 & 8.7 \\
\hline \multicolumn{7}{|c|}{ Association D - Elphidium excavatum/Miliammina fusca (stns 40, 43) } \\
\hline Elphidium excavatum & 63.2 & 0.3 & 1.0 & 10.0 & 57.1 & 64.3 \\
\hline Miliammina fusca & 15.9 & 0.6 & 1.0 & 8.5 & 7.4 & 28.6 \\
\hline Trochammina inflata & 5.7 & 0.7 & 1.0 & 7.0 & 1.6 & 21.3 \\
\hline Buccella frigida & 1.9 & 0.6 & 1.0 & 4.5 & 0.3 & 15.1 \\
\hline Ammonia beccarii & 9.3 & 0.1 & 1.0 & 8.0 & -20.3 & 11.9 \\
\hline
\end{tabular}

Association E - Ammonia beccarii/Haynesina depressula (stns 3, 4, 5, 7, 10, 13, 16, 17, 18, 20, 21, 23, 25, 26, 29, 32, 33, 37, 38)

\begin{tabular}{|c|c|c|c|c|c|c|}
\hline Ammonia beccarii & 55.2 & 0.2 & 1.0 & 9.9 & 25.6 & 49.6 \\
\hline Haynesina depressula & 11.5 & 0.2 & 1.0 & 7.9 & 4.0 & 21.0 \\
\hline Elphidium excavatum & 5.3 & 0.0 & 0.7 & 3.9 & -0.8 & 9.8 \\
\hline Elphidium advenum & 4.3 & -0.1 & 0.6 & 4.6 & 0.2 & 9.5 \\
\hline Buccella frigida & 2.7 & 0.2 & 0.5 & 2.6 & 1.2 & 8.2 \\
\hline Bolivina cf. translucens & 3.3 & 0.1 & 0.5 & 3.3 & -1.2 & 7.6 \\
\hline Elphidium charlottensis & 1.9 & 0.0 & 0.7 & 2.7 & -3.3 & 6.3 \\
\hline Textularia earlandi & 2.0 & 0.2 & 0.4 & 1.7 & 0.2 & 5.9 \\
\hline
\end{tabular}

Association F - Bolivina cf. translucens/Textularia earlandi/Bolivina subexcavata (stns 6, 19, 24, 30)

$\begin{array}{lrrrrrr}\text { Bolivina cf. translucens } & 20.6 & 0.6 & 1.0 & 7.3 & 16.1 & 31.4 \\ \text { Textularia earlandi } & 8.8 & 0.5 & 0.8 & 4.0 & 7.0 & 17.6 \\ \text { Bolivina subexcavata } & 10.5 & 0.2 & 0.5 & 4.8 & 9.0 & 16.9 \\ \text { Elphidium charlottensis } & 6.3 & 0.3 & 1.0 & 5.0 & 1.1 & 15.7 \\ \text { Trochammina sorosa } & 4.2 & 0.7 & 0.8 & 3.3 & 3.7 & 15.2 \\ \text { Astrononion novozealandicum } & 6.3 & 0.3 & 0.5 & 3.3 & 5.4 & 12.9 \\ \text { Haynesina depressula } & 5.3 & 0.2 & 1.0 & 4.8 & -2.3 & 12.7 \\ \text { Elphidium advenum } & 4.8 & 0.1 & 0.8 & 5.0 & 0.7 & 12.0 \\ \text { Ammonia beccarii } & 9.1 & 0.1 & 1.0 & 7.5 & -20.5 & 11.2 \\ \text { Siphouvigerina glabra } & 2.7 & 0.5 & 0.8 & 1.5 & 1.7 & 10.8 \\ \text { Reophax arctica } & 1.8 & 0.7 & 0.8 & 0.5 & 1.6 & 10.5 \\ \text { Gavelinopsis lobatulus } & 1.5 & 0.4 & 0.8 & 1.3 & 0.5 & 8.7 \\ \text { Rotaliammina bartrami } & 1.3 & 0.5 & 0.5 & 0.8 & 1.1 & 7.7 \\ \text { Fissurina lucida } & 1.0 & 0.5 & 0.8 & 0.0 & 0.4 & 7.4\end{array}$

Association G - Elphidium charlottensis/ Patellinella incospicua/Quinqueloculina seminula (stns 1, 2, $8,9,11,12,14,15,27,28,31,34,39$ )

Elphidium charlotttensis

Patellinella inconspicua

Quinqueloculina seminula

Haynesina depressula

Ammonia beccarii

Oolina tasmanica

Elphidium advenum

Gavelinopsis lobatulus

Nonionellina flemingi

Cassidulina carinata

Zeaflorilus parri

$13.0 \quad 0.4$

0.6
0.6

1.0

1.0

0.9

5.1

7.2

0.2

14.7

0.2
0.1

4.3

5.9

$\begin{array}{ll}0.7 & 0.9\end{array}$

1.0
1.0

2.6

2.2

0.3

0.9

$\begin{array}{ll}0.6 & 0.8\end{array}$

$\begin{array}{ll}0.7 & 0.9\end{array}$

$\begin{array}{ll}1.6 & 0.7\end{array}$

0.7
0.6

0.9

2.8

0.6
0.6

7.8
5.7
4.4
5.6
7.2
2.6
4.2
1.8
0.8
0.8
1.5
1.6

\begin{tabular}{rr}
7.8 & 24.8 \\
4.4 & 20.1 \\
3.2 & 16.4 \\
-0.4 & 15.5 \\
-14.9 & 15.4 \\
2.5 & 15.1 \\
1.8 & 13.6 \\
1.6 & 11.3 \\
1.4 & 11.3 \\
1.0 & 11.2 \\
1.9 & 10.5 \\
1.7 & 10.4 \\
\hline
\end{tabular}

Table 1. Main characterizing species of the seven benthic foraminiferal associations recognized in Pauatahanui Inlet. Species are arranged in order of decreasing Association scores (Assoc score) calculated from each species abundance (Abund), fidelity (Fid), persistence (Pers), dominance (Dom) and relative abundance (Rel) within each association (see text for explanation) 
outer and middle parts of the inlet and as a wide zone across the inlet between the more saline outer and middle parts and the brackish shallow upper reaches (Fig. 4).

Ammonia beccarii is dominant throughout the association (30-90\% of the fauna in samples, mean $55 \%$ ). Haynesina depressula is usually the secondary dominant (mean $12 \%$ abundance). Common associated taxa are the dominants of surrounding associations, e.g. Elphidium excavatum, E. charlottensis, Bolivina cf. translucens, Textularia earlandi.

Associations dominated by Ammonia are common worldwide in similar lower estuary environments (Murray, 1991).

\section{Association F - Bolivina cf. translucens/Textularia earlandi/Bolivina subexcavata}

Depth : 1-2.4 m. Sediment : mud to slightly shelly, muddy, very fine sand.

This association occurs in the middle of the inlet (3 stations) and in a backwater to one side of the mouth and entrance channel of the inlet. All samples are in very fine sediment in quiet parts of the inlet, probably with lowered oxygen concentration in the surface sediment.

The characterizing taxa together with Ammonia beccarii are the four dominant species in this association. Other common taxa that mainly occur in this association (high fidelity and relative abundance) are Trochammina sorosa, Astrononion novozealandicum, Siphouvigerina glabra, Reophax arctica, Rotaliammina bartrami and Fissurina lucida.

This association is unusual. Textulari earlandi is a common constituent of near normal salinity lower estuarine associations worldwide but seldom in association with Bolivina (Murray, 1991).

\section{Association G - Elphidium charlottensis/Patellinella inconspicua/Quinqueloculina seminula}

Depth : high tide to $10 \mathrm{~m}$. Sediment : fine sandy mud to shelly, slightly muddy, fine sand.

This association occurs in the mouth, entrance channel and central portion of the outer and middle parts of the inlet. It occurs in fine sediment at all depths in both strongly current swept localities and quieter backwaters. All are clustered around the mouth and entrance channel which provide a fresh flush of normal salinity water into the inlet during each tidal cycle.

The characterizing species are Elphidium charlottensis, Patellinella inconspicua and Quinqueloculina seminula, mainly because of their high relative abundances in this association. The faunas are dominated (5-15\% each) by these three characterizing species, together with Ammonia beccarii, Haynesina depressula and Elphidium advenum. The latter three are codominants in adjacent association $\mathrm{E}$.

Many species that occur commonly in shallow, normal marine environments, are mainly confined to this association in the present study area. These include Patellinella inconspicua, Quinqueloculina seminula, Oolina tasmanica, Gavelinopsis lobatulus, Nonionellina flemingi, Cassidulina carinata, Zeaflorilus parri and Discorbis dimidiatus.

Elphidium and Quinqueloculina seminula are commonly

\begin{tabular}{lrrl}
\hline & $S$ & $H_{(s)}$ & $E$ \\
\hline Association A & 5.0 & 0.84 & 0.46 \\
Association B & 4.0 & 0.47 & 0.40 \\
Association C & 9.2 & 1.37 & 0.46 \\
Association D & 7.5 & 1.16 & 0.45 \\
Association E & 11.7 & 1.45 & 0.40 \\
Association F & 21.0 & 2.33 & 0.51 \\
Association G & 26.9 & 2.73 & 0.58 \\
\hline
\end{tabular}

Table 2. Mean values for species diversity ( $S=$ species number; $H_{(S)}=$ Information Function) and evenness $(E)$ for the seven foraminiferal associations recognised in Pauatahanui Inlet.

the dominants in shallow water normal salinity environments in middle latitudes worldwide, but Patellinella has not been recorded as an additional characterizing species outside of New Zealand (Murray, 1991).

\section{Planktic foraminifera}

The tests of planktic forms comprise 0 to $4 \%$ of the total foraminiferal faunas. Planktic forms are only present in the more saline associations $E-G$ suggesting that they have been carried by tidal currents into Pauatahanui Inlet from more open waters.

Species diversity (Table 2, Fig. 5)

There is a general trend of increasing diversity (as measured by species number $S$, and Information Function $H$ ) from the most brackish faunas around the head of Pauatahanui Inlet (associations A, B, D) through to the most saline, and most mixed, nearer the mouth $(F, G)$. The three lowest diversity associations (A, B, D) are all in mid- to high tidal situations around the head of the inlet. The brackish, intertidal association $\mathrm{C}$ (Miliammina-Haplophragmoides) has a similar low diversity $(S, H)$ to the slightly more saline, intertidal and subtidal association $\mathrm{E}$ (AmmoniaHaynesina). There is a marked jump up in diversity then to the more saline (and most mixed) associations $F$ and $G$.

The two most saline associations near the inlet mouth ( $F$ and $G$ ), have the highest evenness scores (E) reflecting the more even spread of dominance of their diverse faunas. Associations $\mathrm{E}$ and $\mathrm{B}$ have the lowest evenness scores reflecting the high dominance of Ammonia beccarii and Trochammina inflata, respectively. These overall trends of increasing diversity and increasing evenness from brackish to saline and from intertidal to deeper water are similar to those observed elsewhere in the world and are useful guides in palaeoenvironmental interpretation of extinct shallow or brackish water foraminiferal faunas.

\section{ARE THE ASSOCIATIONS REAL?}

Are the seven benthic foraminiferal associations recognized here (Fig. 4), distinctive faunal entities likely to recur many times in nature, or are they artificial divisions applied to a gradually changing faunal pattern? Are these associations recurring combinations of species that have considerable 


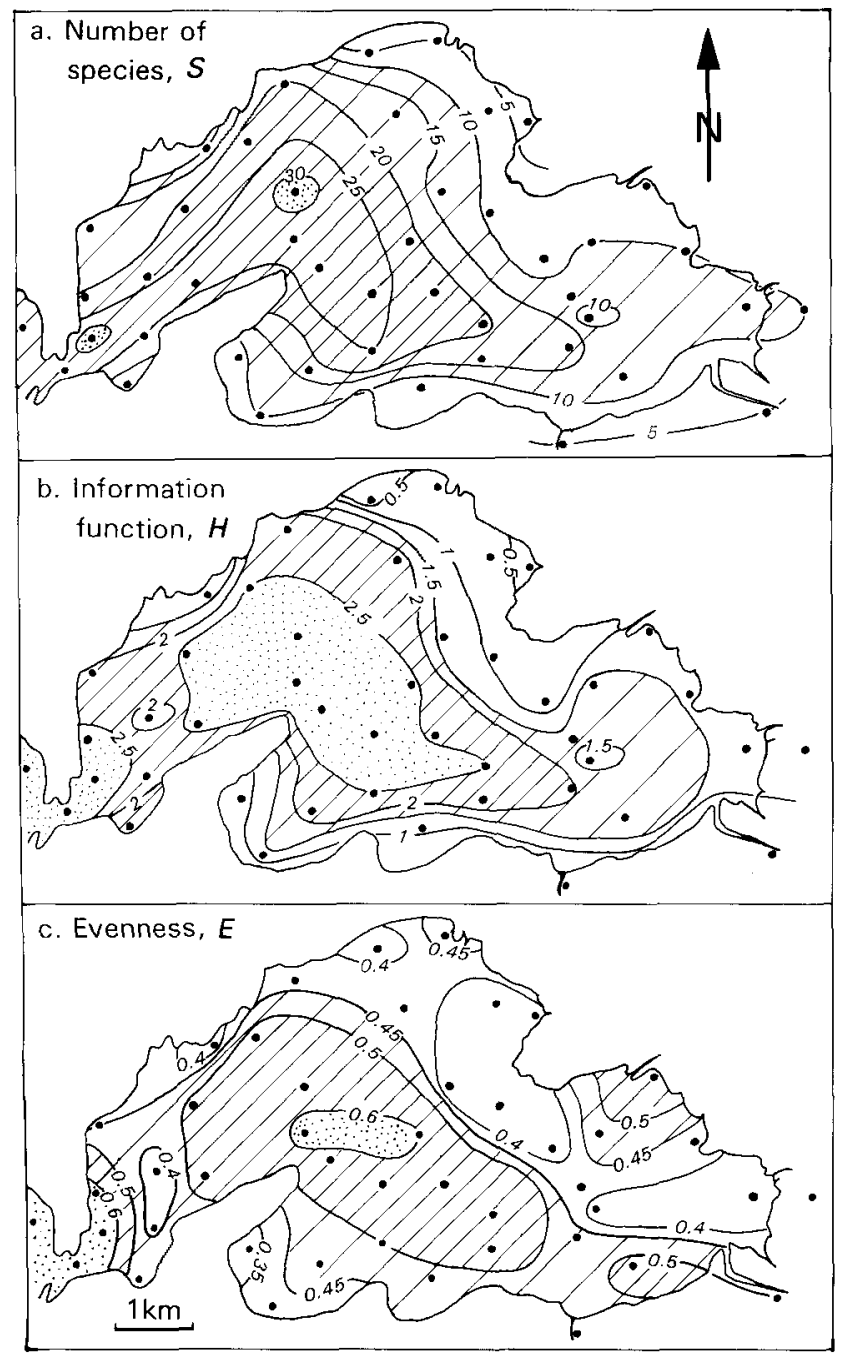

Fig. 5. Contoured maps of benthic foraminiferal species diversity in Pauatahanui Inlet, using diversity measures $S=$ number of species in pick of 100 benthic forms; $H=$ Information Function; and $E=$ evenness.

spatial extent and/or occur in environments having consistent abiotic attributes?

The authors of any study such as this, producing putative associations, must ask whether their suggested associations have any general validity or are they merely artefacts of the particular data set under consideration.

Non-hierarchical clustering techniques attempt to minimize some criterion or function of the distance(s) between points within each cluster. They are iterative, refining the inital clustering and offer no guarantee that their output represent a global minimum of the clustering criterion. Frequently different initial assignments of stations to clusters produces output clusters which also differ. This nondeterminancy can be used to test the robustness of any reported clusters or associations. If many differing initial random subdivisions of the stations are input to the method, the resulting outputs can be compared. It was found that all initial subdivisions produced very similar patterns with only a few stations (near the boundaries of E,F and $G$ ) not consistently falling into particular associations. Thus the seven associations are not a purely random subdivision of a continuum, but the most natural subdivision with the most distinctive boundaries that can be determined using the data available. Even so, quick perusal of the characterizing species lists (Table 1) shows that each association is not taxonomically discrete and that adjacent associations often grade into each other, sharing many species in common.

Examination of the individual distributions of the more common species in Pauatahanui Inlet (Fig. 6) shows them to have non-random distributions apparently related to combinations of physical factors. Several patterns are apparent. Some widely distributed species have relatively low background densities but several clumps of much greater abundances (e.g. Ammonia beccarii, Bolivina cf. translucens, Buccella frigida, Elphidium advenum, $E$. excavatum, Haynesina depressula). Several other widespread species have a single peak area with abundances decreasing gradually away from it (e.g. Elphidium charlottensis, Miliammina fusca, Patellinella inconspicua, Quinqueloculina seminula). Other species with more restricted distributions have one or more high density peaks (e.g. Bolivina subexcavata, Trochammina inflata, Trochamminita irregularis, Textularia earlandi). Other less abundant species have their total distribution restricted to certain parts of the inlet and are never faunal dominants (e.g. Haplophragmoides wilberti, Jadammina macrescens).

Although the distribution of no two species exactly coincide, there is considerable approximate coincidence, especially approximate coincidence of peak densities. In places there is also consistent peripheral overlap of species' distributions that appear to occur in similar environmental conditions. It is these coincidences and overlaps that generally produce the recognized associations.

In the computer analysis it was found that the strongest subdivision was two-fold into a brackish group (associations $A-D)$ and a more saline group $(E-G)$. This distinct break is clearly seen in the distribution patterns of individual species (Fig. 6). Five of the more common species are almost exclusively confined to the brackish group of associations; ten are almost exclusively confined to the more saline group and only Elphidium excavatum straddles the boundary. Within the brackish group, associations $A$ and D are each primarily produced by the abundance peak of only their dominant species (Trochamminita irregularis and Elphidium excavatum respectively) whereas associations $\mathrm{B}$ and $\mathrm{C}$ are both produced by the coincidences of the abundance peaks of their two characterizing species with highest association scores (B-Trochammina inflata, Jadammina macrescens; C-Miliammina fusca, Haplophragmoides wilberti).

Boundaries between the more saline associations (E-G) are more gradational but the associations are defined by the abundance coincidences and overlaps of a greater number of species than in the brackish group. Association $\mathrm{E}$ is produced by the abundance peak of Ammonia beccarii and its approximate coincidence with peak abundances of Haynesina depressula. These overlap with the peripheral 

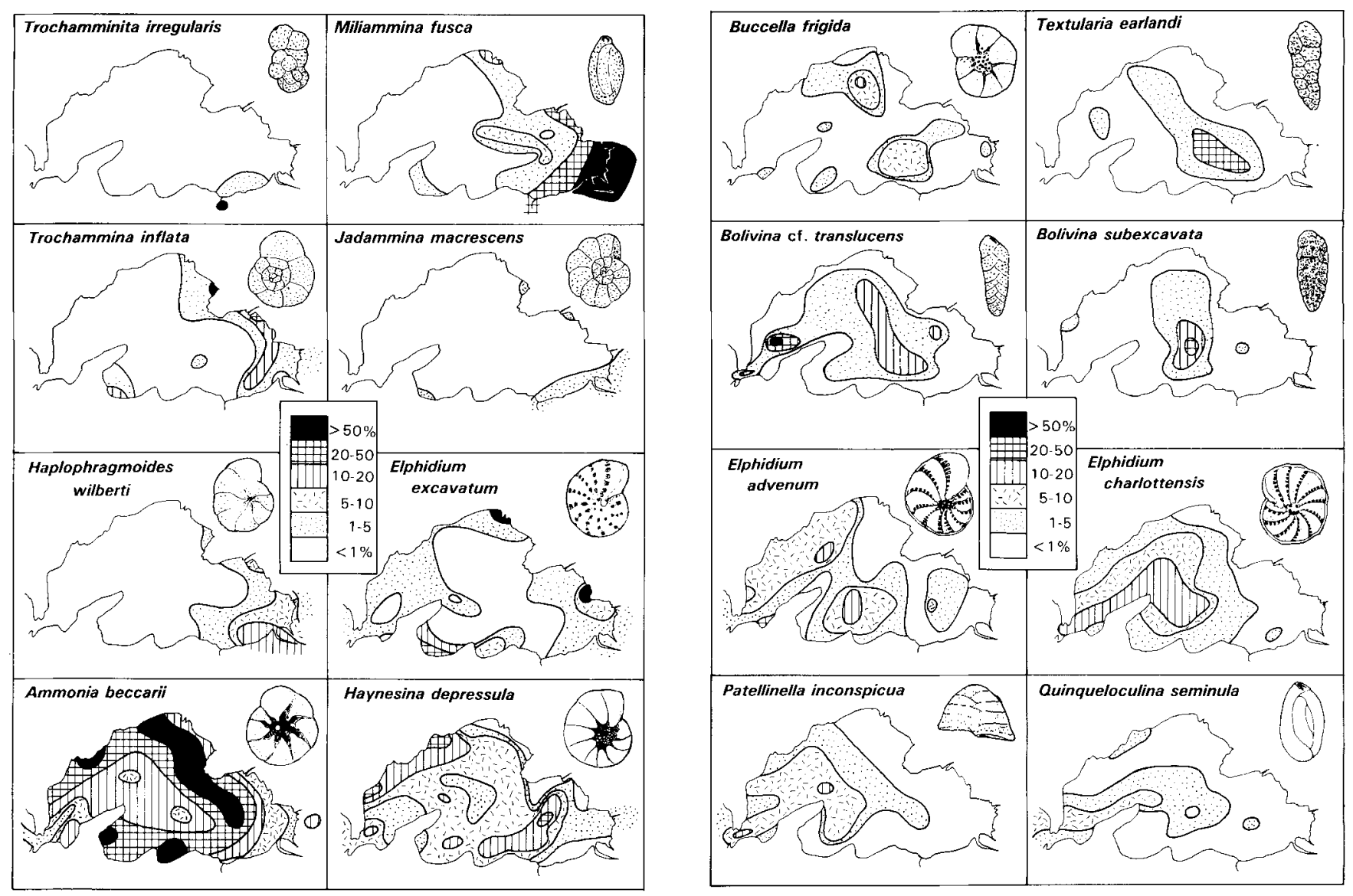

Fig. 6. Contoured abundance distribution maps of the dominant characterizing species of the foraminiferal associations in Pauatahanui Inlet.

distributions of many of the common and characterizing species of associations D, F and G. Association F is produced by the very approximate coincidence of the abundance peaks of widespread Bolivina cf. translucens and more restricted Textularia earlandi and Bolivina subexcavata, together with the more precise coincidence of abundance peaks and sometimes entire distributions of rarer Astrononion novozealandicum, Reophax arctica, Rotaliammina bartrami, Siphouvigerina glabra and Trochammina sorosa (Table 1). Association $G$ is produced by the moderately close coincidence of the abundance peaks of Elphidium charlottensis and Patellinella inconspicua together with the spatial distribution of Quinqueloculina seminula and most of the distribution of a long string of rarer species (e.g. Cassidulina carinata, Discorbis dimidiatus, Gavelinopsis lobatulus, Nonionellina flemingi, Oolina tasmanica, Zeaflorilus parri).

Thus these associations are distinctive faunal entities, although not discrete as they grade into neighbouring associations. The 7-fold subdivision adopted is the most natural obtainable from the data. It is obvious that the fauna is not distributed randomly nor in a uniformly changing continuum and thus the associations are not purely artificial subdivisions. Recognition of associations does tend to obscure the individual distributions of species and the natural gradations from one association into the next.
Within Pauatahanui Inlet, most recognized associations (except A, B and D) have considerable spatial and mappable extent and their distributions appear to be related to consistent abiotic factors. All associations (except F) are characterized by combinations of species that are known to recur in similar environments elsewhere in New Zealand, e.g. Brook et al., 1981 (G); Gregory, 1973 (C,E); Hayward, $1981(B, G)$; Hayward \& Hollis, in press (A-E).

Thus in most respects we consider these associations to be real and their recognition and mapping to be one of the best ways of portraying and understanding the natural faunal pattern.

\section{RELATIONSHIP OF ASSOCIATIONS TO ENVIRONMENTAL FACTORS}

The relationship between the sample (via the species) scores and the environmental factors is displayed on the biplots (Figs 7,8 ) produced using the Canonical Correspondence Analysis (Ter Braak 1987). The length of the arrow, indicating the axis and direction of increasing values of an environmental factor, is a measure of the correlation between that factor and the faunal pattern. It was found that the three factors - proportion of gravel, sand and mud were highly correlated, as expected. Consequently the fitted relationships between the species (and hence the sample 


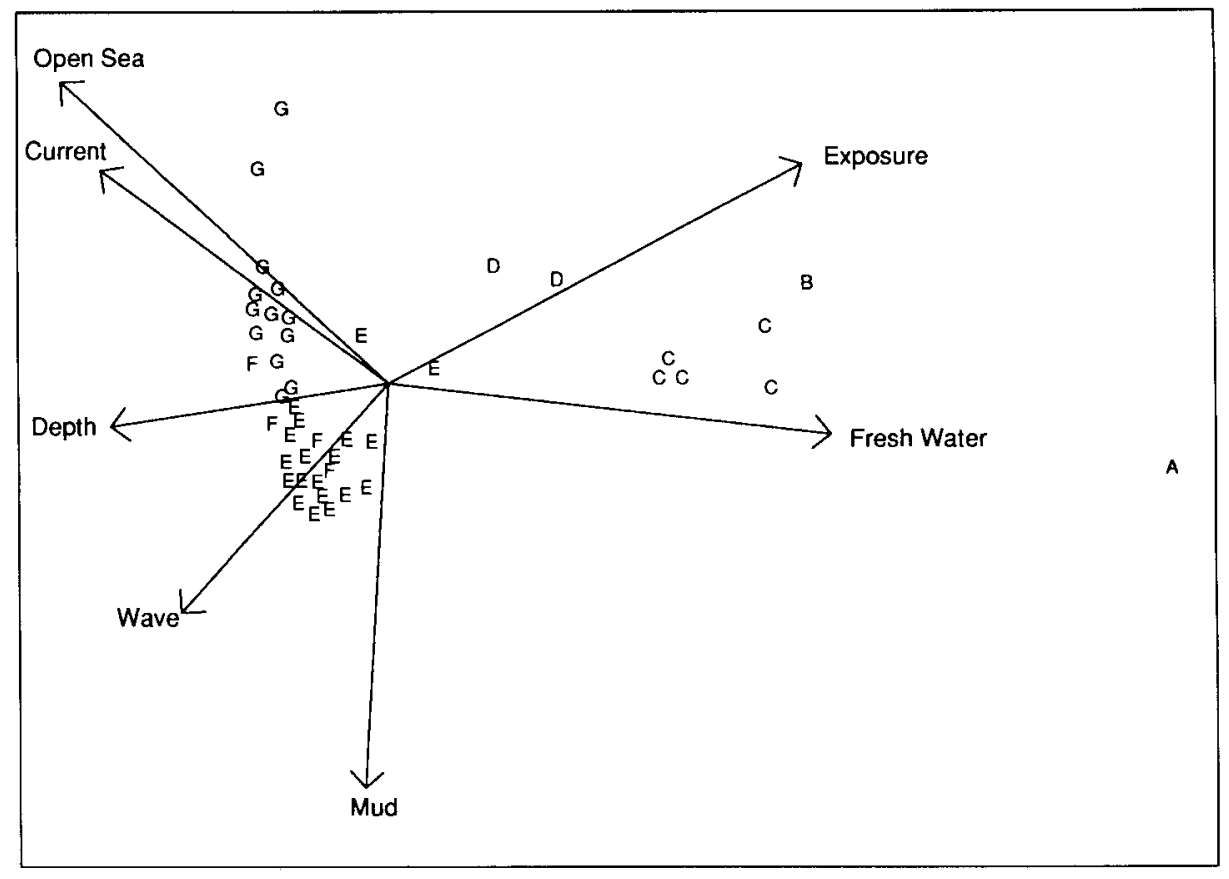

Fig. 7. Two-dimensional configuration of samples produced by Detrended Correspondence Analysis (Fig. 3) with the seven associations and the axes of the more highly correlated environmental factors (produced by Canonical Correspondence Analysis) superimposed. The dimensions plotted jointly explain $55 \%$ of the variation in the data.

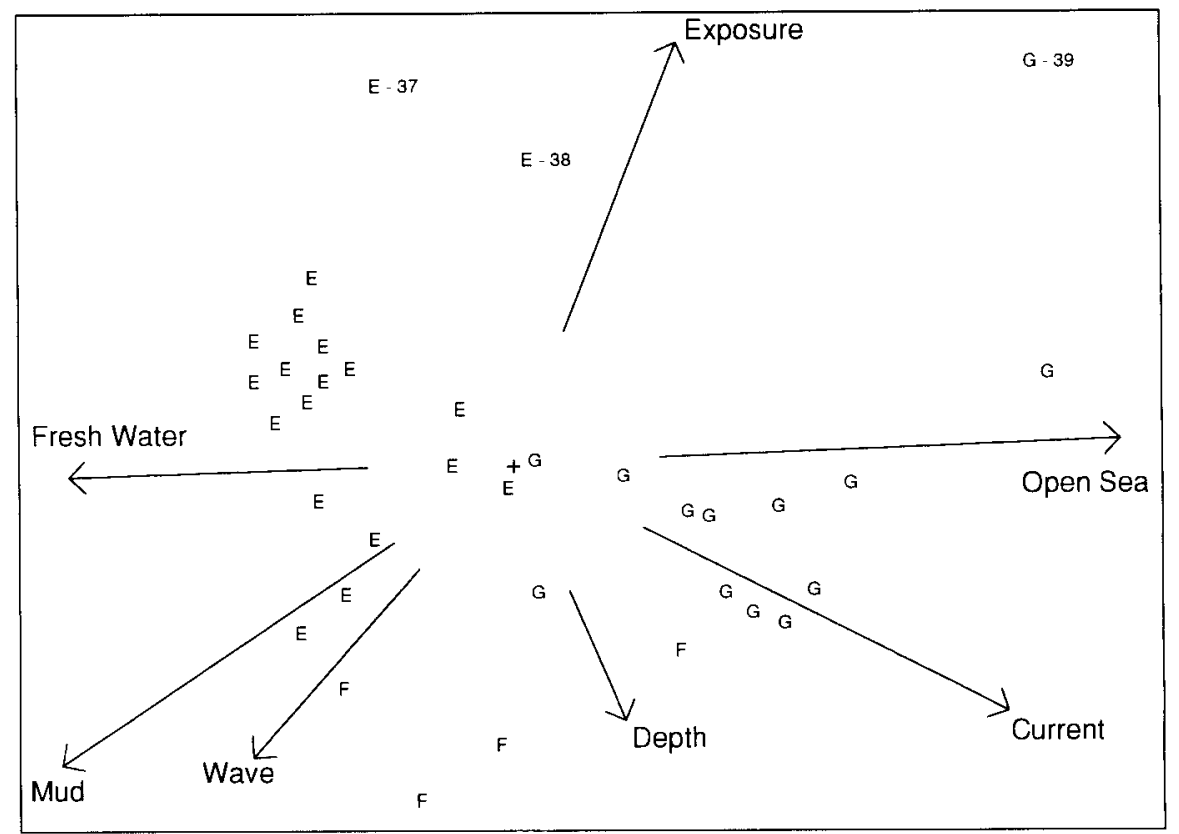

Fig. 8. Two-dimensional configuration of samples in the more saline associations (E-G) produced by Detrended Correspondence Analysis with the three associations and the axes of the more highly correlated environmental factors (produced by Canonical Correspondence Analysis) superimposed. The two dimensions plotted jointly explain $62 \%$ of the variation in the data. 
scores) and these variables were unstable. Only the factor, mud, was retained for subsequent analysis.

The biplot derived from the full data set is shown in Fig. 7. The strongest associations are with the environmental factors, open sea, exposure and freshwater, and these three factors appear to be largely responsible for producing the pattern of associations. Freshwater (low salinity) and exposure (the proportion of time a station is exposed above the tide level) factors appear to be the two main environmental influences that split the faunas into saline and brackish groups. The more saline associations, E, F and G, have approximately constant values when projected onto the axes for these two factors. These two factors however seem to be responsible for most of the differentiation between the four associations within the brackish group. Association A is the least saline, followed by B and C then D. Associations A and $B$ also differ from $C$ and $D$ in having greater exposure.

The data from the three saline associations (E, F and $G$ ) were also analysed separately to determine which environmental factors, if any, differentiate the associations (Fig. 8). The environmental factors having greatest influence appear to be: proximity to open sea, tidal current strength and percentage of mud. Association $G$ is differentiated from $\mathrm{E}$ and $\mathrm{F}$ by being closest to the open sea, having the highest salinity, the least mud, and generally the strongest tidal currents. Association E is the furthest from the open sea, has the strongest freshwater influence and the weakest currents in this group. Association F appears to be influenced by a combination of high mud content and factors related to greater water depth.

There is considerable residual variation within these saline faunal associations. The biplot (Fig. 8) suggests which environmental factors have the greatest influence on the intra-association variability. It can be seen that faunas in stations 37, 38 and 39 differ considerably from other members of associations $\mathrm{E}$ and $\mathrm{G}$. These stations lie in the direction of increasing exposure and are indeed the only intertidal samples in these associations. Other factors that strongly correlate with intra-association faunal variability and may be producing it include mud content (in associations $\mathrm{E}$ and $\mathrm{F}$ ), and tidal current strength (in association $\mathrm{G}$ ).

\section{POST-MORTEM TRANSPORT OF FORAMINIFERAL TESTS}

The strong correlation found between association $G$ and the open sea and tidal current factors suggests that post-mortem transport of foraminiferal tests is probably a significant factor in determining the composition of the faunas in this association.

Strong tidal currents sweep through the narrow channel at the entrance of Pauatahanui Inlet (Fig. 2c) and have potential to carry in (and out) the tests of foraminifera. Outside the entrance, the combination of strong tidal currents, bottom currents and an exposed coast adjacent to turbulent Cook Strait, makes conditions ideal for the tests of normal salinity foraminifera to be lifted into suspension and transported into the inlet (see Murray et al., 1982). Association $\mathrm{G}$ is best characterized as a mixture of taxa that lived in the area (e.g. Bolivina cf. translucens, Elphidium charlottensis) and those that have been transported in from open sea areas outside the inlet (e.g. Nonionellina flemingi, Cassidulina carinata) and more brackish areas within the inlet (e.g. Ammonia beccarii, Haynesina depressula).

The distinctiveness of the brackish associations and the high fidelity values for the characterizing species in associations A-C (Table 1) suggests that post-mortem transport and faunal mixing is of little consequence around the head of the inlet, where there are low current strengths (Fig. 2c).

\section{ACKNOWLEDGEMENTS}

We are grateful to the New Zealand Oceanographic Institute for providing splits of many of their sediment samples to form the basis of this study. Debbie Fincham prepared the quantitative picks of benthic foraminifera; Chris Hollis drafted many of the figures; Barry Burt, Sue Bishop and Wendy St George (New Zealand Geological Survey) are responsible for the SEM photomicrographs. We thank Chris Hollis (Auckland Museum), Marty Buzas (Smithsonian Institution) and George Scott (New Zealand Geological Survey) for reading the draft manuscript and for suggesting improvements. The work was begun at the New Zealand Geological Survey and DSIR Applied Mathematics Division, and completed at Auckland Museum and University with funding assistance from the New Zealand Foundation for Research, Science and Technology.

\section{Manuscript received October 1992 \\ Manuscript accepted November 1993}

\section{APPENDIX 1: LIST OF FORAMINIFERA IDENTIFIED FROM PAUATAHANUI INLET}

BENTHIC FORMS

Suborder Textulariina

Ammotium fragile Warren

Gaudryina convexa (Karrer)

Haplophragmoides wilberti Andersen

Jadammina macrescens (Brady) (Pl. 1, 3-5)

Miliammina fusca (Brady) (Pl. 1,9)

Reophax arctica Brady (Pl. 1, 15)

Rotaliammina bartrami (Hedley, Hurdle \& Burdett) (Pl. 1, 10-11)

Rotaliammina cf. trumbulli Seiglie \& Bermudez

Siphotextularia mestayerae Vella

Textularia ensis Vella

Textularia earlandi Brady (Pl. 1, 14)

Trochammina inflata (Montagu) (Pl. 1, 7-8)

Trochammina sorosa Parr (Pl. 1, 12-13)

Trochamminita irregularis Cushman \& Bronnimann (Pl. 1, 6).

Suborder Miliolina

Cyclogyra involvens (Reuss)

Massilina brodiei Hedley et al.

Miliolinella schauinslandi (Rhumbler)

Miliolinella subrotundata (Montagu)

Miliolinella cf. vigilax Vella 


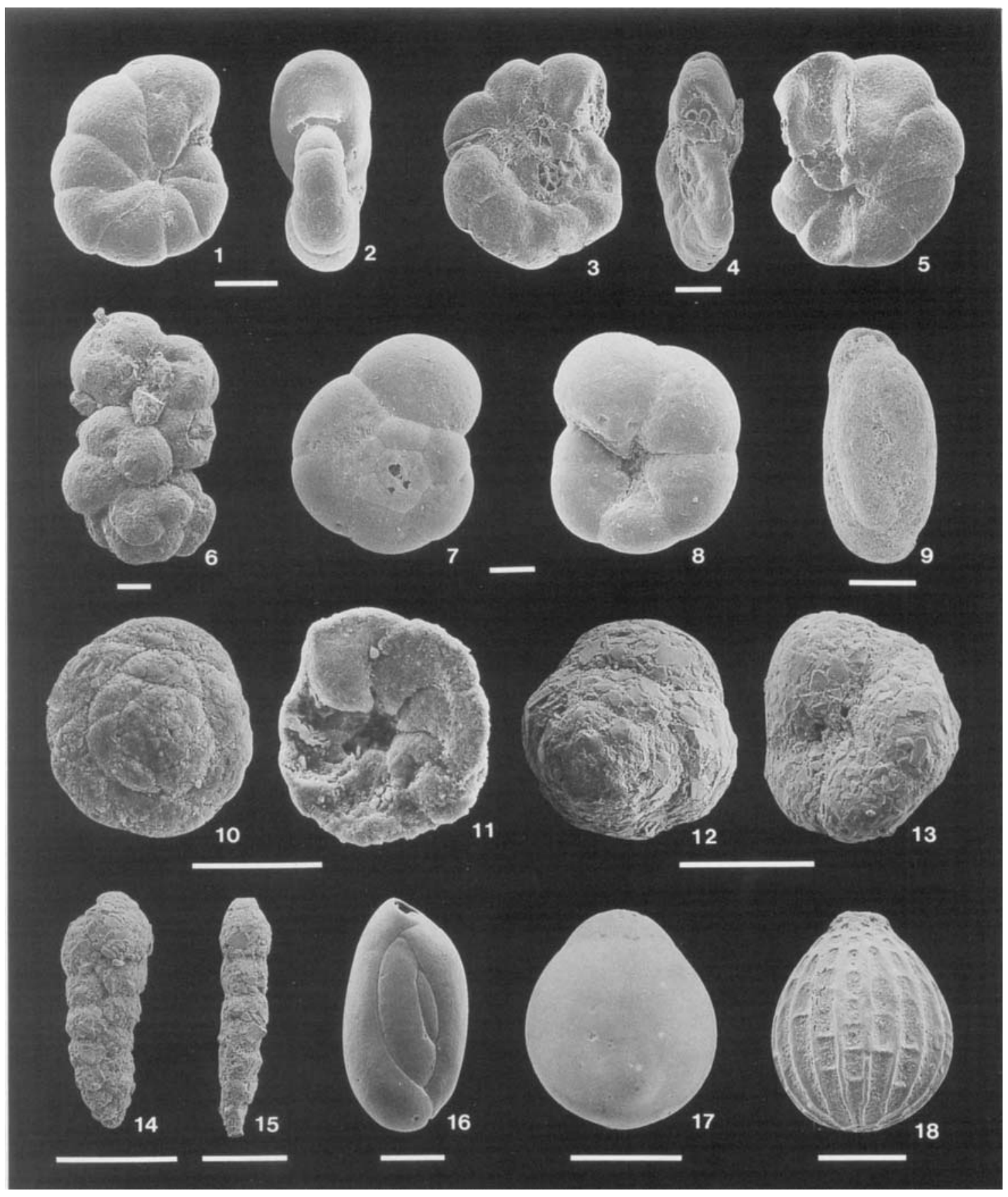

Plate 1 
Pyrgo ezo Asano

Quinqueloculina agglutinans D'Orbigny

Quinqueloculina colleenae Vella

Quinqueloculina cooki Vella

Quinqueloculina delicatula Vella

Quinqueloculina aff. lata Terquem

Quinqueloculina parvaggluta Vella

Quinqueloculina seminula (Linnaeus) (Pl. 1, 16)

Quinqueloculina tenagos Parker

Quinqueloculina triangularis d'Orbigny

Triloculina trigonula (Lamarck)

Suborder Rotaliina

Acervulina inhaerens Schulze

Ammonia beccarii (Linnaeus) (Pl. 2, 8-9)

Anomalina spherica Finlay

Astrononion novozealandicum Cushman \& Edwards (Pl. 2,

15)

Bolivina cacozela Vella

Bolivina compacta Sidebottom

Bolivina hornibrooki Collen

Bolivina pseudoplicata Heron-Allen \& Earland

Bolivina robusta Brady

Bolivina spathulata (Williamson)

Bolivina striatula Cushman

Bolivina subexcavata Cushman \& Wickenden (Pl. 2, 2)

Bolivina cf. translucens Phleger \& Parker (Pl. 2, 1)

Bolivinita pliozea Finlay

Buccella frigida (Cushman) (Pl. 2, 6-7)

Bulimina gibba Fornasini

Bulimina marginata d'Orbigny

Bulimina patagonica d'Orbigny

Bulimina submarginata Parr

Buliminella elegantissima (d’Orbigny)

Cassidulina carinata Silvestri

Cibicides cf. corticatus Earland

Cibicides lobatulus (Walker \& Jacob)

Cibicides marlboroughensis Vella

Cibicides ef. ungerianus (d'Orbigny)

Dentalina communis D'Orbigny

Discorbinella vitrevoluta (Hornibrook)

Discorbis dimidiatus (Jones \& Parker) (P1. 2, 4)

Dyocibicides sp.

Elphidium advenum (Cushman) (Pl. 2, 11).

Elphidium charlottensis (Vella) (Pl. 2, 12)

Elphidium excavatum (Terquem) (Pl. 2, 10)

Elphidium novozealandicum Cushman

Epistominella exigua (Brady)

Evolvocassidulina orientalis (Cushman)

Fissurina claricurta McCulloch

Fissurina lucida (Williamson) (Pl. 1, 17).

Fissurina marginata (Montagu)
Fissurina cf. orbignyana Seguenza

Florilus turgida (Williamson)

Fursenkoina schreibersiana (Czjzek)

Gavelinopsis hamatus Vella

Gavelinopsis lobatulus (Parr) (P1. 2, 5)

Globocassidulina minuta (Cushman)

Guttulina irregularis (d'Orbigny)

Guttulina yabei Cushman \& Ozawa

Gypsina vesicularis (Parker \& Jones)

Hanzawaia bertheloti (D'Orbigny)

Hanzawaia complanata Sidebottom

Haynesina depressula (Walker \& Jacob) (Pl. 2, 13)

Lagena flatulenta Loeblich \& Tappan

Lagena lyelli (Seguenza)

Lagena sulcata spicata Cushman \& McCulloch

Lenticulina australis Parr

Loxostomum karrerianum (Brady)

Nonion pacificum (Cushman)

Nonionellina flemingi (Vella)

Notorotalia depressa Vella

Notorotalia finlayi Vella

Notorotalia inornata Vella

Notorotalia zealandica Finlay

Oolina hexagona (Williamson)

Oolina tasmanica Parr (Pl. 1, 18).

Patellina corrugata Williamson

Patellinella inconspicua (Brady) (Pl. 2, 14)

Pileolina patelliformis (Brady)

Pileolina radiata Vella

Pileolina zealandica Vella

Planodiscorbis rarescens (Brady)

Planulinoides planoconcava (Chapman, Parr \& Collins)

Rectobolivina singaporensis McCulloch

Rosalina bradyi (Cushman)

Rosalina irregularis (Rhumbler)

Rosalina paupereques Vella

Rosalina terquemi (Rzehak)

Rosalina cf. valvulata D'Orbigny

Sigmoidella elegantissima (Parker \& Jones)

Sigmoidella kagaensis Cushman \& Ozawa

Siphouvigerina glabra Millett (Pl. 2, 3)

Trifarina carinata (Cushman)

Trifarina carinata bradyana (Cushman)

Trifarina n.sp.

Uvigerina peregrina Cushman

Virgulopsis turris (Heron-Allen \& Earland)

Zeaflorilus parri (Cushman) (Pl. 2, 16-17)

PLANKTIC FORMS

Globigerina falconensis Blow

Globigerina quinqueloba Natland

Globigerinita glutinata (Egger)

\section{Explanation of Plate 1}

Scanning electron microscope photographs of characterizing and more common species in Pauatahanui Inlet. Scale equals $0.1 \mathrm{~mm}$. Figs 1-2, Haplophragmoides wilberti, FP3995-6. Figs 3-5, Jadammina macrescens, FP3997-8. Fig. 6, Trochamminita irregularis, FP3999. Figs 7-8, Trochammina inflata, FP4000-1. Fig, 9, Miliammina fusca, FP4002. Figs 10-11. Rotaliammina bartrami, FP4003-4. Figs 12-13, Trochammina sorosa, FP4005-6. Fig. 14, Textularia earlandi, FP4007. Fig. 15, Reophax arctica, FP4008. Fig. 16, Quinqueloculina seminula, FP2841. Fig. 17, Fissurina lucida, FP4009. Fig. 18. Oolina tasmanica, FP4010. 


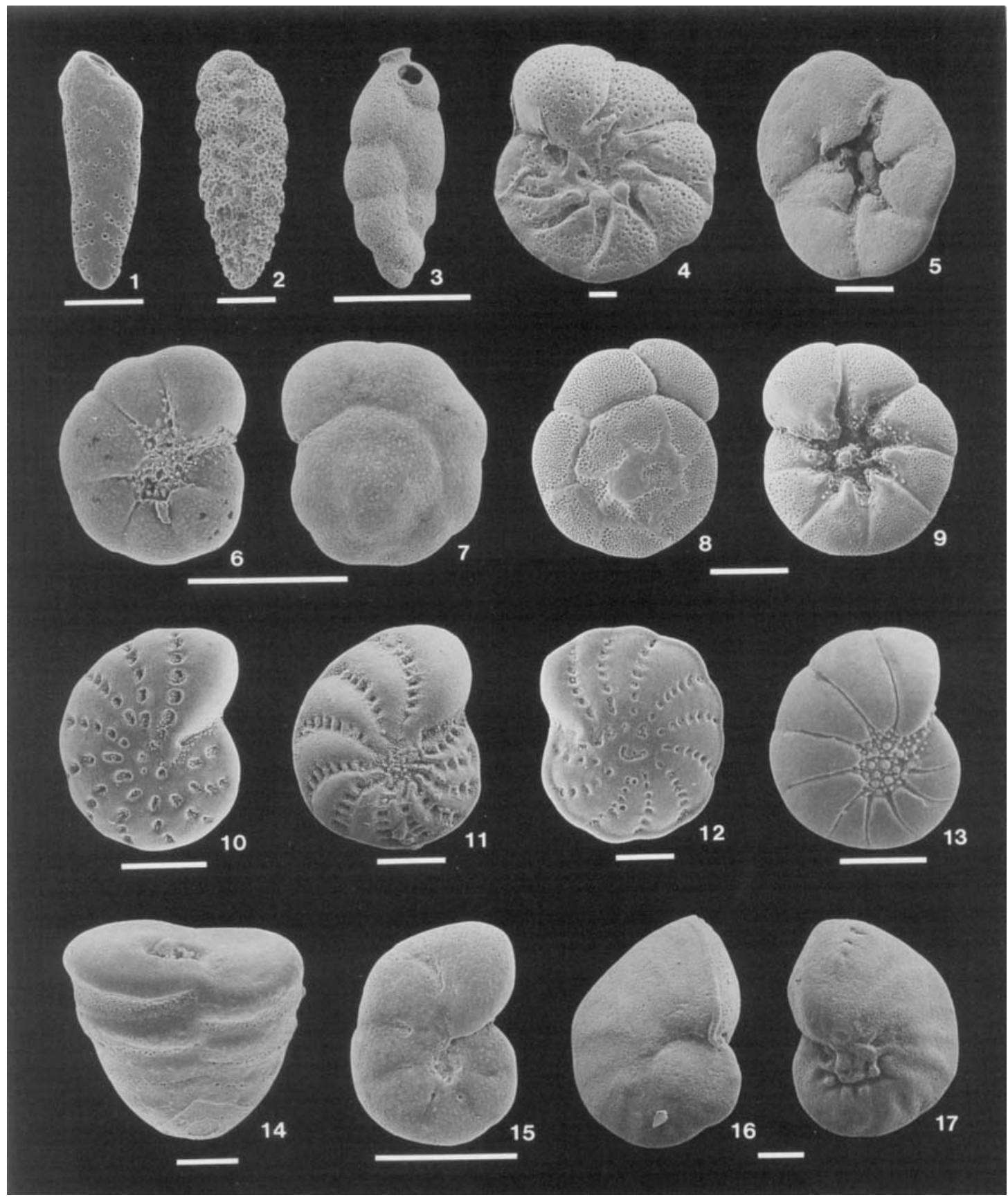

Plate 2 
Globorotalia inflata (d'Orbigny)

Neogloboquadrina dutertrei (d'Orbigny)

Neogloboquadrina pachyderma (Ehrenberg)

Orbulina universa D'Orbigny

\section{REFERENCES}

Banfield, C. F. \& Bassill, L. C. 1977. A transfer algorithm for Non-hierarchical Classification. Applied Statistics, 26: 206-210.

Brook, F. J., Grace, R. V. \& Hayward, B. W. 1981. Soft-bottom benthic faunal associations of Tutukaka Harbour, Northland, New Zealand. Tane, Auckland, 27: 69-92.

Buzas, M. A. \& Gibson, T. G. 1969. Species diversity, benthonic foraminifera in western North Atlantic. Science, 163: 72-75.

Gibson, T. G. \& Buzas, M. A. 1973. Species diversity: Patterns in modern and Miocene foraminifera of the eastern margin of North America. Geological Society of America Bulletin, 84: 217-238.

Grange, K. R. 1979. Soft-bottom macrobenthic communities of Manukau Harbour, New Zealand. New Zealand Journal of Marine and Freshwater Research, Wellington, 13: 315-329.

Gregory, M. R. 1973. Benthonic foraminifera from a mangrove swamp, Whangaparapara, Great Barrier Island. Tane, Auckland, 19: $193-203$.

Hayward, B. W. 1981. Foraminifera in near-shore sediments of the eastern Bay of Islands, New Zealand. Tane, Auckland, 27: $123-134$.

Hayward, B. W. \& Hollis, C.J. in press. Brackish foraminifera in New Zealand: A taxonomic and ccologic review. Micropaleontology.
Healy, W. B. (ed.) 1980. Pauatahanui Inlet - an environmental study. DSIR Information Series 141, Wellington.

Hill, M. O. 1973. Diversity and evenness: a unifying rotation and its consequences. Ecology, 54: 427-432.

Irwin, J. 1978. Pauatahanui Inlet Bathymetry 1:5000. New Zealand Oceanographic Institute chart, Miscellaneous Series No. 47.

MacArthur, R. H. \& MacArthur, J. W. 1961. On bird species diversity. Ecology, 42, 594-598.

McCloskey, L. R. 1970. The dynamics of the community associated with a marine scleractinian coral. Internationale Revue der Gesamten Hydrobiologie, 55: 13-82.

McDougall, J. C. 1976. Distribution of surface sediments of Pauatahanui Inlet. New Zealand Oceanographic field report No. 7.

McDougall, J. C. 1978. Pauatahanui Inlet Sediments 1:5000. New Zealand Oceanographic Institute chart, Miscellaneous Series No. 50.

Murray, J. W. 1991. Ecology and paleoecology of benthic foraminifera. Longman Scientific and Technical, England.

Murray, J. W., Sturrock, S. \& Weston, J. F. 1982. Suspended load transport of foraminiferal tests in a tide- and wave-swept sea. Journal of Foraminiferal Research, 12: 51-65.

Payne, R. W. et al. 1987. GENSTAT 5 Reference Manual. Clarendon Press, Oxford.

Ter Braak, C. J. F. 1985. CANOCO-A FORTRAN program for canonical correspondence analysis and detrended correspondence analysis. IWIS-TNO, Wageningen, The Netherlands.

Ter Braak, C. J. F. 1987. The analysis of vegetation-environment relationships by canonical correspondence analysis. Vegetatio, 69: $69-77$.

\section{Explanation of Plate 2}

Scanning electron microscope photographs of characterizing and more common species in Pauatahanui Inlet. Scale equals $0.1 \mathrm{~mm}$. Fig 1 , Bolivina cf. translucens, FP4011. Fig. 2, Bolivina subexcavata, FP4012. Fig. 3, Siphouvigerina glabra, FP4013. Fig. 4, Discorbis dimidiatus, FP3164. Fig. 5, Gavelinopsis lobatulus, FP4014. Figs 6-7, Buccella frigida, FP4015-6. Figs 8-9, Ammonia beccarii, FP4017-8. Fig. 10, Elphidium excavatum, FP4019. Fig. 11, Elphidium advenum, FP4020. Fig. 12, Elphidium charlottensis, FP4021. Fig. 13, Haynesina depressula, FP4022. Fig. 14, Patellinella inconspicua, FP3505. Fig. 15, Astrononion novozealandicum, FP4023. Figs 16-17, Zeaflorilius parri, FP4024-5. 